\title{
Structural and Thermomechanical Study of Plastic Films Made from Cassava-Starch Reinforced with Kaolin and Metakaolin
}

\section{Namory Meite ${ }^{1}$, Léon Koffi Konan ${ }^{*}$, Drissa Bamba², Bi Irié Hervé Goure-Doubi ${ }^{3}$, Samuel Oyetola ${ }^{1}$}

\author{
${ }^{1}$ Laboratory of Materials Chemistry, Felix Houphouet Boigny University, Cocody-Abidjan, Ivory Coast \\ ${ }^{2}$ Laboratory of Water Chemistry, Training School of Abidjan (ENS), Abidjan, Ivory Coast \\ ${ }^{3}$ Laboratory of Biological Sciences, Péléforo Gon Coulibaly University of Korhogo, Korhogo, Ivory Coast \\ Email: *namorymeite2986@gmail.com, *leonkonan2000@yahoo.fr
}

How to cite this paper: Meite, N., Konan, L.K., Bamba, D., Goure-Doubi, B.I.H. and Oyetola, S. (2018) Structural and Thermomechanical Study of Plastic Films Made from Cassava-Starch Reinforced with Kaolin and Metakaolin. Materials Sciences and Applications, 9, 41-54.

https://doi.org/10.4236/msa.2018.91003

Received: November 2, 2017

Accepted: January 2, 2018

Published: January 5, 2018

Copyright $\odot 2018$ by authors and Scientific Research Publishing Inc. This work is licensed under the Creative Commons Attribution International License (CC BY 4.0).

http://creativecommons.org/licenses/by/4.0/

\begin{abstract}
The structural and thermomechanical properties of starch-based plastic films reinforced with kaolin and metakaolin have been studied by various techniques (X-ray diffraction, IR-TF spectroscopy, scanning electron microscopy, tensile tests, and thermal resistance). The results obtained showed that kaolin, an inert material, prevents the starch from losing its granular structure and to solubilize during the heating, generating plastic films of low Young's modulus (7 MPa). On the other hand, metakaolin, an amorphous and dehydroxylated material obtained after heating of kaolin at $700^{\circ} \mathrm{C}$ for 1 hour, substantially improves the thermomechanical properties of the plastic films. The Young's modulus increases from $19 \mathrm{MPa}$ to $25 \mathrm{MPa}$ while the thermal resistance increases from $90^{\circ} \mathrm{C}$ to $120^{\circ} \mathrm{C}$. This was attributed to good dispersion of the metakaolin in the polymer matrix after the loss of the granular structure of the starch during heating.
\end{abstract}

\section{Keywords}

Cassava Starch, Plastic Films, Kaolin, Metakaolin, Stress at Break, Young's Modulus

\section{Introduction}

Plastics are materials whose utility in various fields (food packaging, cosmetic industries, and automobiles ...) is undeniable [1]. The production and use of petrochemical plastics always followed by negative environmental impacts because plastic wastes are non-biodegradable. The emergence of concepts such as sus- 
tainable development and green chemistry has led to the development of biodegradable polymers. Among the natural biopolymers, the starch made up of $98 \%$ $99 \%$ of a mixture of two natural polymers (amylose and amylopectin) is considered the most promising raw material for the development of new environmental friendly materials. Unlike synthetic polymers, plastic films based on starch have little resistance to water and have weak thermomechanical properties, which can be improved by the formulation of composites. In fact, the introduction of mineral fillers makes it possible to improve the mechanical properties without interfering with the biodegradability of the composites [2]. The clay, finely divided materials, appears to be good reinforcements because of its physicochemical properties such as large surface area, strong shape anisotropy or their electrical charge.

Traditionally used as raw material for pottery, clay is increasingly used in various fields for specific applications [3]. They are used in the chemical industry where they initiate certain reactions [4] [5]. Some are used for their high adsorption capacity in the treatment of polluted water, to filter wines, beers. They are also used in the pharmaceutical and medical industries where they serve as the basis for wound dressings [6]. During the last two decades, many construction works have been done where they are used as building materials (stabilized earth bricks or ceramic tiles [7] [8]). In the field of mineral-polymeric composites, montmorillonite-type clays are commonly used because of their readiness to disperse easily. On the other hand, kaolinite-type clays remain very little used because of their non-expansible nature in the polymer matrix, despite the great abundance of kaolinitic deposits [9]. A less cohesive kaolinite has often been obtained through chemical treatment with dimethylsulfoxide (DMSO) [10]. Another way of restructuring the crystalline structure of kaolinite is by heat treatment above $700^{\circ} \mathrm{C}[11]$.

The aim of this work is to elaborate and characterize the structural and thermomechanical properties of plastic films based on cassava starch reinforced with kaolin and metakaolin obtained after heat treatment of kaolin at $700^{\circ} \mathrm{C}$ for 1 hour.

\section{Experimental Techniques and Materials}

\subsection{Materials}

The cassava starch used in this work for the production of plastic films was obtained from the market. Before use, it was dried on a metal plate until a constant mass was obtained.

The mineral filler was a kaolin purchased from the company DAMREC (France) its chemical and mineralogical compositions are given in Table 1 [12]. Metakaolin was obtained after heat treatment at $700^{\circ} \mathrm{C}$ of this kaolin, for one hour with a rising rate of $5^{\circ} \mathrm{C} / \mathrm{min}$ in a programmable furnace of the NABERTHERM model. 
Table 1. Chemical and mineralogical composition of kaolin (wt\%) [12].

\begin{tabular}{|c|c|c|c|c|c|c|c|c|c|}
\hline Chemical & $\mathrm{SiO}_{2}$ & $\mathrm{Al}_{2} \mathrm{O}_{3}$ & $\mathrm{Fe}_{2} \mathrm{O}_{3}$ & $\mathrm{~K}_{2} \mathrm{O}$ & $\mathrm{TiO}_{2}$ & $\mathrm{Na}_{2} \mathrm{O}$ & $\mathrm{CaO}$ & $\mathrm{MgO}$ & $\begin{array}{c}\mathrm{I} . \mathrm{L}^{*} \\
\text { (at } 1000^{\circ} \mathrm{C} \text { ) }\end{array}$ \\
\hline Composition & 51.6 & 34.7 & 0.7 & 0.3 & 0.1 & 0.1 & - & 0.1 & 12.7 \\
\hline $\begin{array}{l}\text { Mineralogical } \\
\text { Composition }\end{array}$ & \multicolumn{9}{|c|}{ Kaolinite $=83$; Illite $=6$; Quartz $=10$; Anatase $=$ trace } \\
\hline
\end{tabular}

\subsection{Experimental Techniques}

The X-ray diffractograms were obtained using a Siemens equipment D5000 model equipped with a copper anti-cathode $(\lambda=1.54 \AA)$. The analyzes were carried out on powder material with a grain size of less than $100 \mathrm{~m}$ in the range $5^{\circ}<$ $2 \theta<60^{\circ}$ with a pitch of $0.02^{\circ}$ and a counting time of 10.1 seconds per step.

Infrared (IR) spectra were obtained using a Fourier Transform spectrometer technique with Perkin Elmer Spectrum 1000 series. The spectral resolution was $4.0 \mathrm{~cm}^{-1}$. The pellets are made from an intimate mixture of sample $(1 \mathrm{mg})$ and potassium bromide $(180 \mathrm{mg})$ then compressed under pressure. The microstructure observation of the samples was carried out using a scanning electron microscope the model Cambridge Stereo scan 260 series. The metallization was carried out by the deposition of layers on/Pd.

Tensile tests were carried out using a tensile dynamometer KERN CH Version 2.7. The device is provided with a fixing clip. The force is exerted vertically and the velocity is assumed to be constant (about $1 \mathrm{~mm} / \mathrm{min}$ ). The applied force is read on the screen of the device and the elongation on the scale incorporated in the device. The thermal resistance of the plastic films was determined at different temperatures using a furnace model NABERTHERM.

The procedure for the production of plastic films is similar to the ones commonly described in the literature [13] [14]. A sample starch (2.5 g) is mixed with $2 \mathrm{ml}$ of glycerol (50\% volume) in the presence of $3 \mathrm{ml}$ of $0.1 \mathrm{M}$ hydrochloric acid. The mineral filler $(0.5 \mathrm{~g})$ is added to the mixture. The whole is homogenized and then heated to $100^{\circ} \mathrm{C}$ on a heating plate equipped with a magnetic stirrer for $10 \mathrm{~min}$. The suspension is then neutralized by the addition of $2 \mathrm{ml}$ of $0.1 \mathrm{M}$ sodium hydroxide solution. Finally, the resulting viscous suspension is poured into petri dishes and then dried at room temperature in 72 hours. The non-reinforced bioplastic is named BP. The bioplastic reinforced with kaolin is named BPK and that reinforced with the metakaolin is named BPMK.

\section{Results and Discussion}

\subsection{Structural and Microstructural Characterization of Starch}

The presence of rays and diffusion halos on the starch powder diffractogram (Figure 1) highlight the semi-crystalline nature of this polymer.

The rays that characterized the three crystalline types of local starches (types A, B and C) are observed from a semi-crystalline material. Indeed, strong reflections are observed at $2 \theta=16.43^{\circ}$ (characteristic of polymorphic C) [15] $17.46^{\circ}$; 




Figure 1. X-ray diffraction spectrum of used cassava starch.

$18.28^{\circ}, 20.77^{\circ}$ and $23.36^{\circ}$ (characteristics of A and B) [16] [17] [18]. Weak reflections also occur at $2 \theta=10.82^{\circ}, 22^{\circ}, 46.15^{\circ}$.

Fourier transform Infrared spectroscopy (FTIR) was used to determine the functional groups present in starch, which is a carbohydrate formula $\mathrm{C}_{6} \mathrm{H}_{10} \mathrm{O}_{5}$ (Figure 2). A strong and wide vibration band centered around $3400 \mathrm{~cm}^{-1}$ is attributed to the bond stretch [19] while a less intense rays at $2930 \mathrm{~cm}^{-1}$ is characteristic of the vibration of asymmetric stretching $\mathrm{C}-\mathrm{H}$ of the aliphatic $-\mathrm{CH}_{2}$ and $-\mathrm{CH}_{2}$ groups [20] [21] [22]. At $1650 \mathrm{~cm}^{-1}$, the vibration band of $\mathrm{H}_{2} \mathrm{O}$ is observed. In the $400 \mathrm{~cm}^{-1}-1600 \mathrm{~cm}^{-1}$ band, the IR spectrum of the starch is characterized by vibration bands at $1400 \mathrm{~cm}^{-1} ; 1350 \mathrm{~cm}^{-1} ; 1219 \mathrm{~cm}^{-1}$ and $1150 \mathrm{~cm}^{-1}$ attributed to the $\mathrm{C}-\mathrm{OH}$ bond stretch vibrations due to the $\mathrm{O}-\mathrm{H}$ alcoholic group and to the $\mathrm{C}-\mathrm{C}$ bond. The vibration bands at $1145 \mathrm{~cm}^{-1} ; 1072 \mathrm{~cm}^{-1} ; 1005 \mathrm{~cm}^{-1} ; 916 \mathrm{~cm}^{-1}$ and $845 \mathrm{~cm}^{-1}$ are relative to the groups; C-O-C, C-O and C-H.

Micrographs of starch obtained through scanning electron microscopy showed round, elliptical, angular and irregular particles with a flattened surface on one side with a tapered hole (Figure 3). As reported in the literature [23], these particles tend to aggregate easily due to the strong interaction of intermolecular and intramolecular hydrogen bonds in the starch.

\subsection{Structural and Microstructural Characterization of Metakaolin}

Figure 4 shows the X-ray diffraction patterns of kaolin and metakaolin. The characteristic rays of kaolinite $\left(2 \theta=12.42^{\circ}\right.$ and $\left.24.71^{\circ}\right)$ and illite $\left(2 \theta=8.77^{\circ}\right.$ and $\left.17.65^{\circ}\right)$ present on the kaolin spectrum are no longer visible on that of the Metakaolin. Only the rays at $2 \theta=20.69^{\circ}$ and $26.67^{\circ}$ corresponded to the presence of quartz are always present. The kaolinite has lost its crystalline structure to become an amorphous material (metakaolinite). The model of layers, stacking along the $\mathrm{c}$ axis in metakaolinite is the same as that of kaolinite. On the other hand, the layer distance is shorter than that in kaolinite. This short range order 


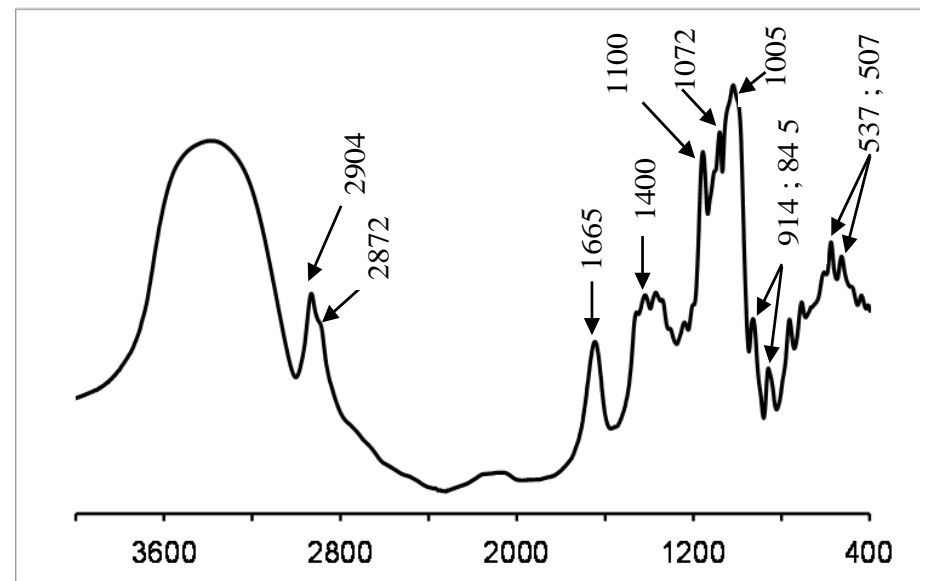

Wavenumber $\left(\mathrm{cm}^{-1}\right)$

Figure 2. Infrared spectrum of used cassava starch.



Figure 3. Scanning electron microscopy of used cassava starch.

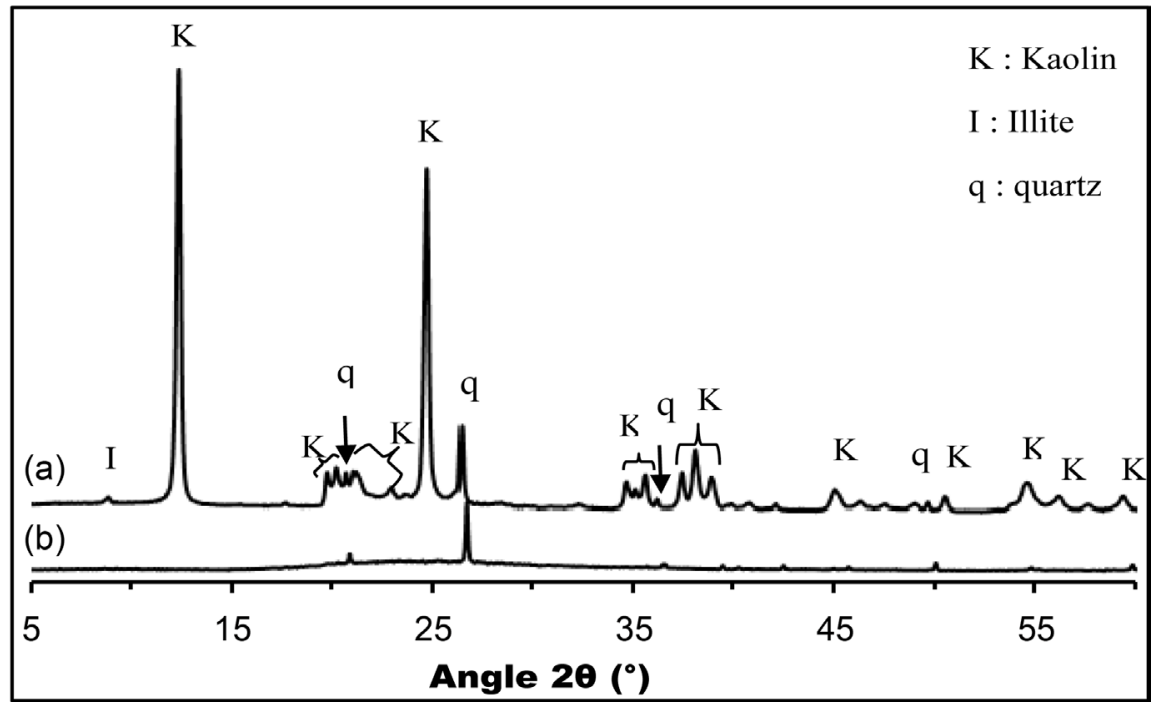

Figure 4. X-ray diffraction spectrum (a) kaolin and (b) metakaolin. 
is not detectable by the X-ray, hence the absence of characteristic rays of kaolinite and illite.

Figure 5 showed the infrared spectra of kaolin and metakaolin. In the 3000 $4000 \mathrm{~cm}^{-1}$ bande, the spectrum of crude kaolin is characterized by the 3696 $\mathrm{cm}^{-1}, 3668 \mathrm{~cm}^{-1}, 3653 \mathrm{~cm}^{-1}$ and $3620 \mathrm{~cm}^{-1}$ bands due to the hydroxyl stretching vibrations. These bands have been the subject of several studies [24] [25]. The band located at $3696 \mathrm{~cm}^{-1}$ was assigned to the hydroxyls of the edges of the interleaf. Those located at $3668 \mathrm{~cm}^{-1}$ and $3653 \mathrm{~cm}^{-1}$ are attributed to the surface hydroxyls of the octahedral layer in interaction with the base oxygen of the adjacent tetrahedral layer. The $3620 \mathrm{~cm}^{-1}$ band is attributed to the internal hydroxyls. No band characterizing the presence of hydroxyl groups was observed on the metakaolin spectrum; expressing that the heat treatment of the kaolin at $700^{\circ} \mathrm{C}$ in 1 hour resulted in a completely dehydroxylated metakaolin.

In the $600-1800 \mathrm{~cm}^{-1}$ band range, the spectrum of the crude kaolin showed the absorption bands at $1112 \mathrm{~cm}^{-1}, 1019 \mathrm{~cm}^{-1}, 798 \mathrm{~cm}^{-1}, 754 \mathrm{~cm}^{-1}$ and $698 \mathrm{~cm}^{-1}$. The band at $1112 \mathrm{~cm}^{-1}$ expressed the stretching vibrations of the Si-O apical bonds while that located at $1019 \mathrm{~cm}^{-1}$ is corresponded to the stretching vibrations of the Si-O-Si bonds. The band located at $914 \mathrm{~cm}^{-1}$ corresponded to the vibrations of the deformation of hydroxyls of the aluminum surface Al-O-H. The bands located at $798 \mathrm{~cm}^{-1}, 754 \mathrm{~cm}^{-1}$ and $698 \mathrm{~cm}^{-1}$ corresponded respectively to $\mathrm{Si}-\mathrm{O}-\mathrm{Al}$ vibrations and hydroxyls perpendicular to the $\mathrm{OH}$ translational) surface [26]. The bands at $476 \mathrm{~cm}^{-1}$ and $432 \mathrm{~cm}^{-1}$ indicated the deformations of the $\mathrm{Si}-\mathrm{O}$ groups while the band at $540 \mathrm{~cm}^{-1}$ indicated the deformation of the $\mathrm{Si}-\mathrm{O}-\mathrm{Al}$ bonds. On the spectrum of metakaolin, profound changes were observed. The bands allocated to the $\mathrm{OH}$ groups and to $\mathrm{Si}-\mathrm{OH}$ vibrations were no longer detectable. This indicated, in addition to dehydroxylation, a profound modification of the alumino-silicate structure of metakaolin. The relatively intense and acute peak at $798 \mathrm{~cm}^{-1}$ observed in the case of kaolin becomes a reduced, wide and displaced towards $810 \mathrm{~cm}^{-1}$ band of the metakaolin spectrum.

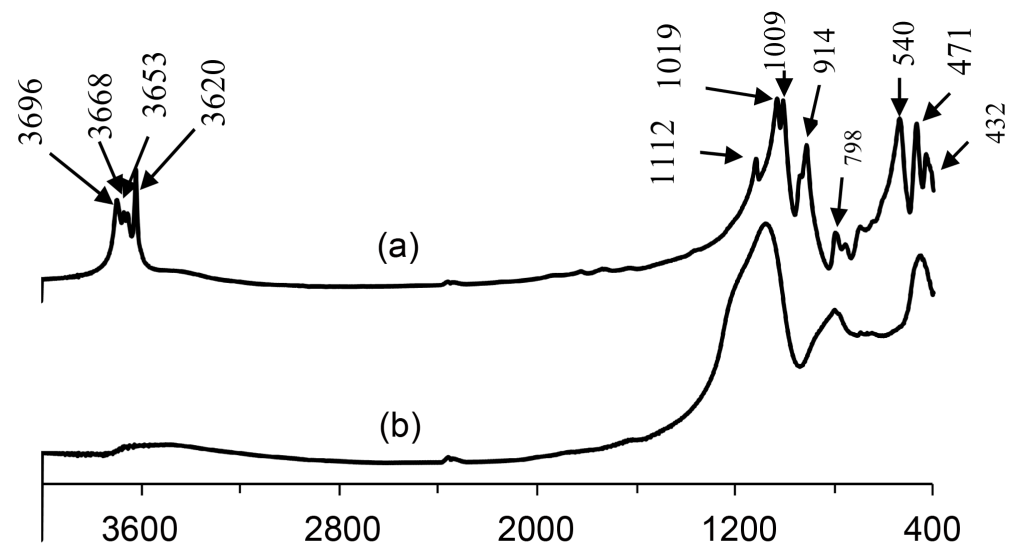

\section{Wavenumber $\left(\mathrm{cm}^{-1}\right)$}

Figure 5. Infrared spectrum (a) kaolin and (b) metakaolin. 
This broad band at $810 \mathrm{~cm}^{-1}$ expressed the degree of structural disorder in metakaolin [27]. These modifications observed in metakaolin indicated a reduction in the cohesion of the layers by the weakening of the hydrogen bonds.

Kaolin is in the shape of hexagonal plates stacked one after the other (Figure 6(a)). Metakaolin platelets resulting from the heat treatment of kaolin have similar but more disordered morphology and more individualized platelets (Figure $6(\mathrm{~b}))$. These observations reveal that the heat treatment of the kaolin at $700^{\circ} \mathrm{C}$ for 1 hour results in dehydroxylation and disorganization of the crystalline structure of the material without a significant change on the morphology of the kaolinite platelets.

\subsection{Visual Appearance of the Elaborated Plastic Films}

All elaborated samples have a homogeneous and smooth surface (Figure 7). The non-reinforced bioplastic (BP) is transparent whereas the two other bioplastics reinforced with kaolin (BPK) reinforced with metakaolin (BPMK) is opaque. This difference is due to the presence of the mineral load. The thickness of the samples was $50 \mu \mathrm{m}$ after drying in Petrie dishes at ambient temperature.
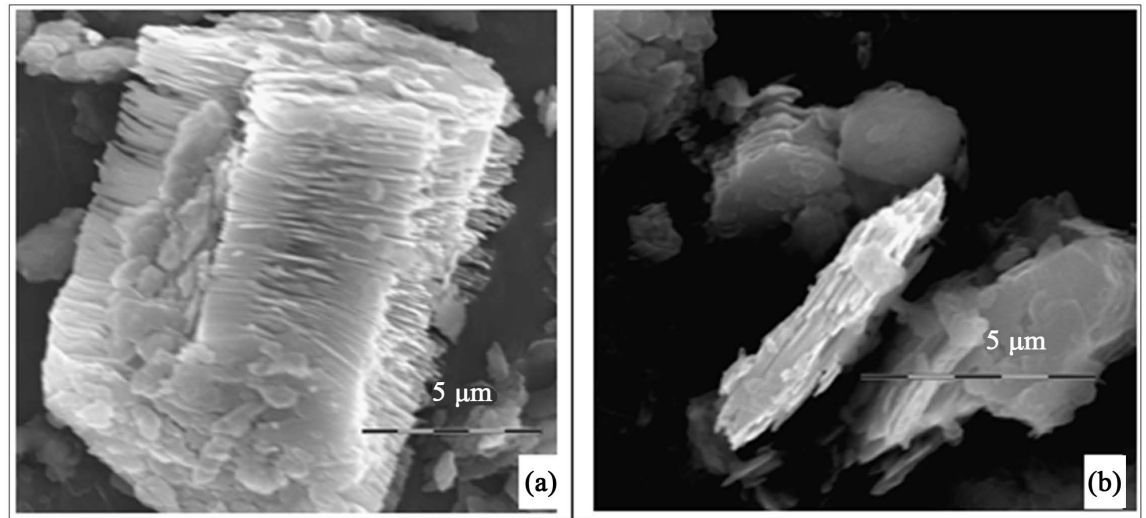

Figure 6. Scanning electron microscopy (a) kaolin and (b) metakaolin.

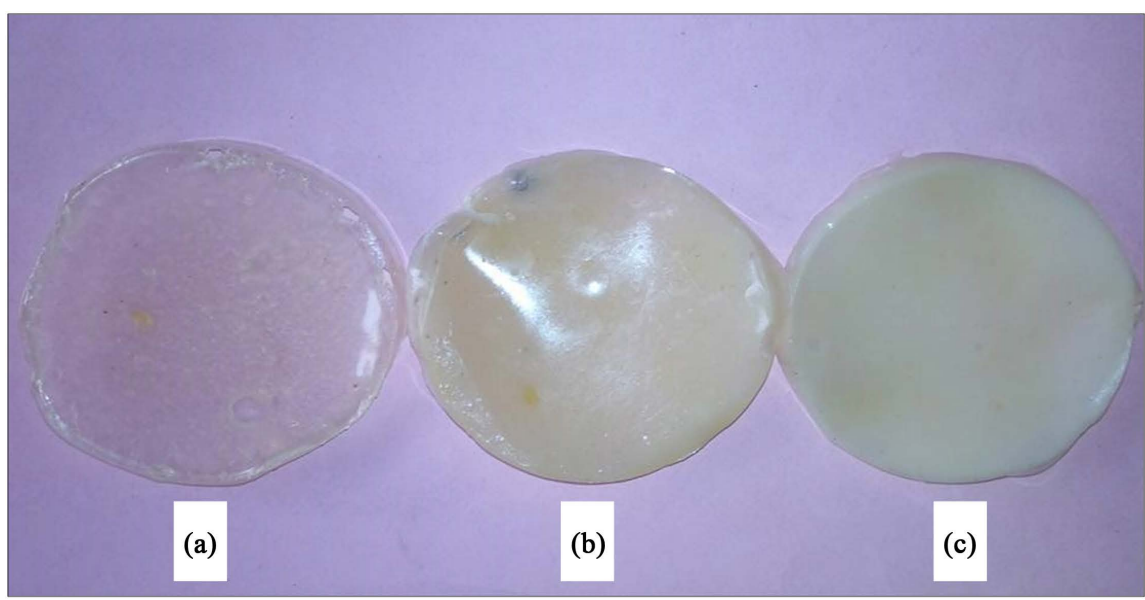

Figure 7. Visual appearance of (a) non-reinforced bioplastic; (b) reinforced with kaolin and (c) reinforced with metakaolin. 


\subsection{Structural and Microstructural Properties of Bioplastics}

The X-ray diffractograms of the various bioplastics (Figure 8) make it possible to observe the influence of the mineral load on their structural properties. The $\mathrm{X}$-ray diffraction spectra of BP and BPMK showed similarities, leaving out the $2 \theta=20.69^{\circ}$ and $26.67^{\circ}$ rays visible on the BPMK spectrum. Indeed, these rays indicated the presence of quartz in the plastic film reinforced with metakaolin. On the other hand, the X-ray diffraction spectrum of BPK revealed notable differences. The characteristic rays of kaolinite and quartz are present in thespectrum. This indicated that kaolin retains its structural integrity in the polymerclay composite.

Figure 9 illustrates the infrared spectra of the reinforced or non-reinforced plastic films. The infrared spectra of BP and BPMK are similar. They are characterized by a strong and broad band centered at $3400 \mathrm{~cm}^{-1}$ due to the stretching

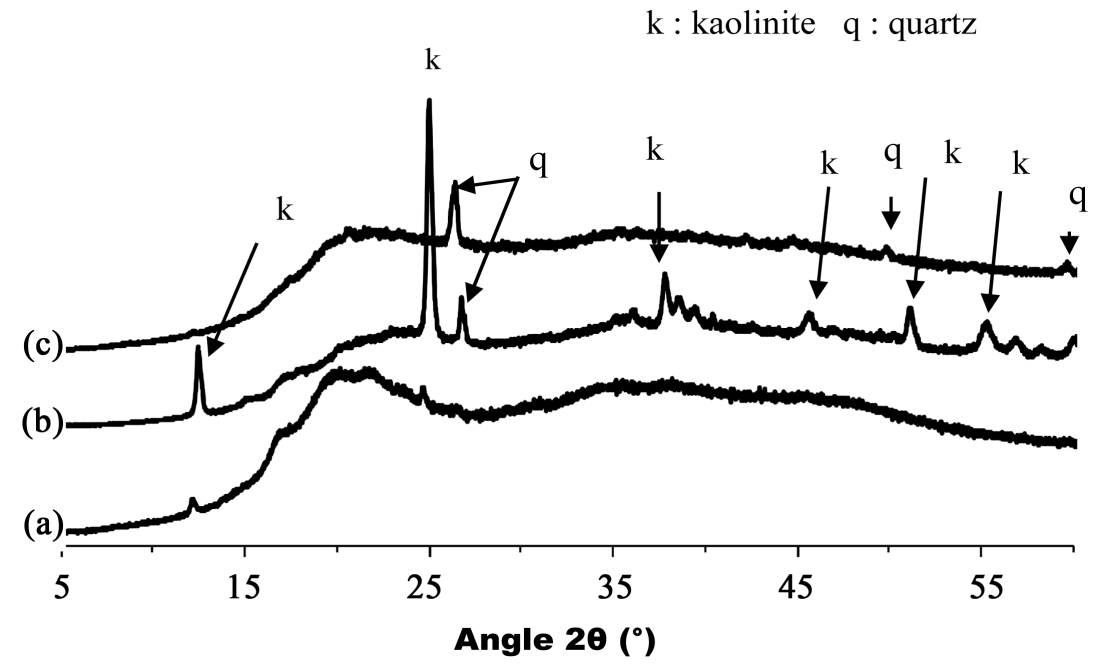

Figure 8. X-ray diffraction spectra of (a) non-reinforced bioplastic; (b) reinforced with kaolin and (c) reinforced with metakaolin.

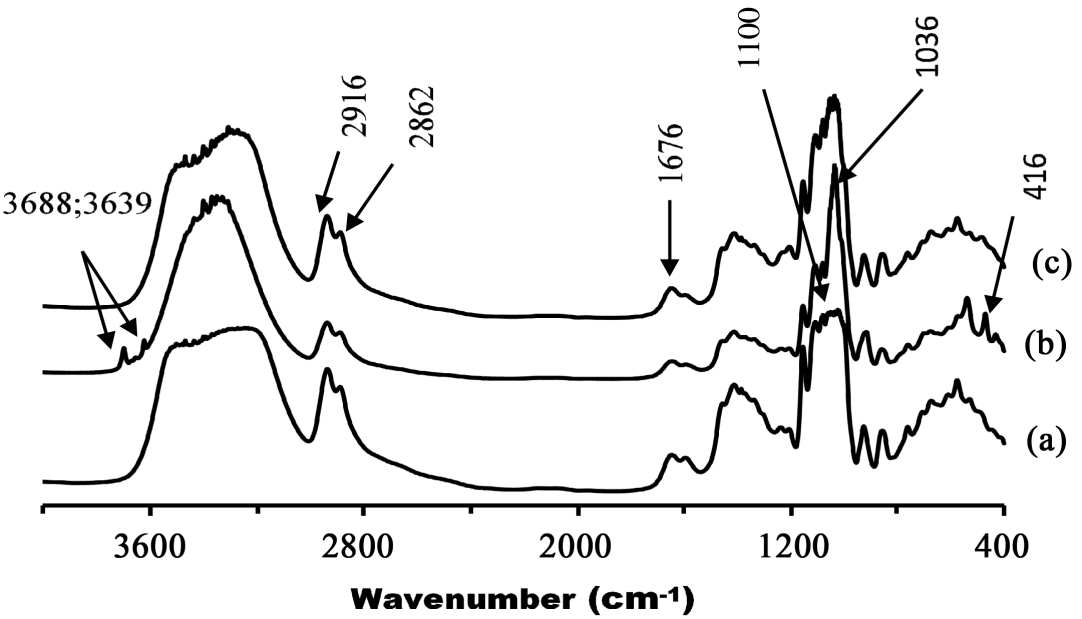

Figure 9. Infrared spectrum of (a) non-reinforced bioplastic; (b) reinforced with kaolin and (c) reinforced with metakaolin. 
vibrations of the $\mathrm{OH}$ groups. On the other hand, for the BPK spectrum, the absorption band centered at $3400 \mathrm{~cm}^{-1}$, is thicker and is similar to that observed in the spectrum of starch. This indicates that the starch has not lost its granular structure despite heating in the presence of kaolin. The $3695 \mathrm{~cm}^{-1}$ and $3670 \mathrm{~cm}^{-1}$ bands, correspond respectively to the hydroxyls of the edges of the layers and to the hydroxides of the surface octahedral layer of the kaolin, are always present confirming the absence of interaction between the hydroxyls and the grains of starch. The absorption band centered on $1100 \mathrm{~cm}^{-1}$ and attributed to the vibration of the C-O-C group of the polymeric chain undergoes profound and different modifications depending on whether the plastic film is reinforced with kaolin or metakaolin. This could be explained by an interaction between theedges of the plates of kaolin and metakaolin made up of cut bonds ( $\mathrm{Si}-\mathrm{O}$ and $\mathrm{Al}-\mathrm{O}$ ) and the polymer.

The micrograph of the plastic films obtained with the scanning electron microscope (Figure 10) showed similarity of structure between the BP and the BPMK. The BPK has a different structure than the other two fore-mentioned. Indeed, during heating of the starch-metakaolin mixture, the solvent penetrates inside the starch grains and causes their swelling. Continued heating of the mixture results in the swelling of the starch grains until they reach a stage where they lose their granular structure: large molecules (essentially amylose) emerge from the grain to be dissolved outside the latter and interact with the metakaolin particles. On the other hand, when the mineral load is kaolin, the solvent is not sufficiently available to allow for enough swelling of the starch grains. Therefore, it can't lose its granular structure and solubilize.

\subsection{Thermomechanical Properties of Bioplastics}

The uniaxial tensile testing was carried out on samples of thickness e $=0.05 \mathrm{~mm}$ and of rectangular section $(0.05 \mathrm{~mm} \times 1.8 \mathrm{~mm})$. Figure 11 showed the evolution of the applied stress $(\sigma)$ as a function of the deformation of the test sample $(\varepsilon)$. All the curves have a linear phase corresponding to an elastic deformation of the plastic films. According to Oudet [28], the elastic deformation is probably due to
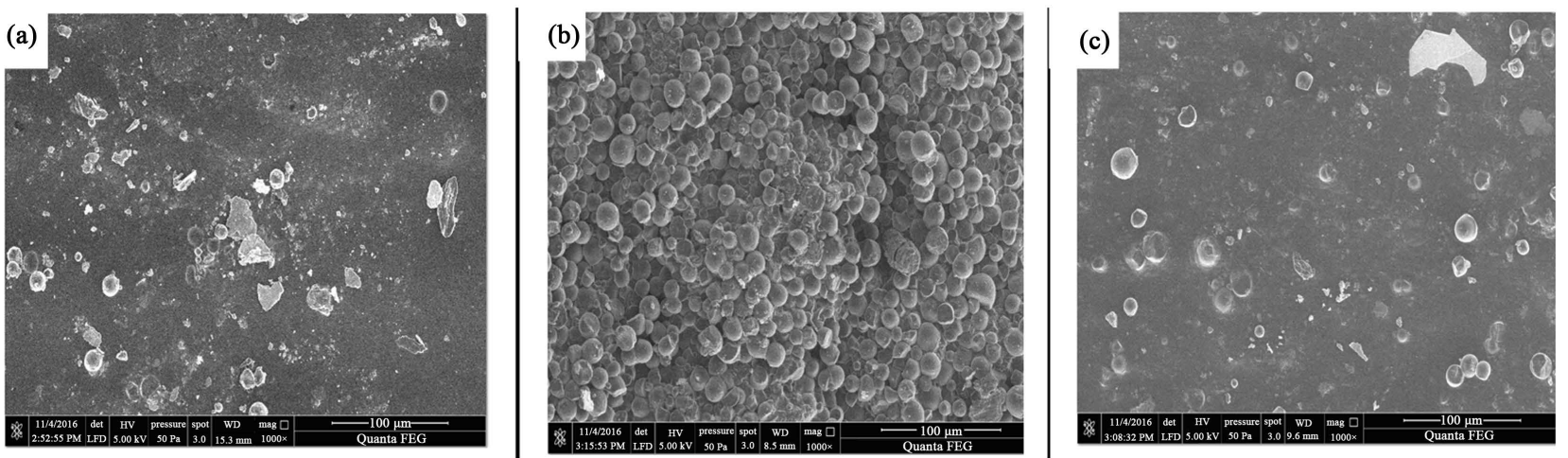

Figure 10. Scanning Electron Microscopy images of (a) non-reinforced bioplastic; (b) reinforced with kaolin and (c) reinforced with metakaolin. 




Figure 11. Evolution of the stress as a function of the stretching of the (a) non-reinforced bioplastic; (b) reinforced with kaolin and (c) reinforced with metakaolin.

the deformation of the valence angle superimposed on the movements of some chains of the amorphous domain. After this phase, a loss of linearity due to a decrease in the cross section of the composites is observed. In this zone, which is referred to as a plastic deformation zone, stress weakening as a function of the deformation due to the occurrence of the intermolecular bond breakdown of hydrogen type is observed.

The physical parameters in tension are given in Table 2.

The Young's modulus values changed from $19 \mathrm{MPa}$ to $25 \mathrm{MPa}$ when the plastic film is reinforced with metakaolin while it drops to $7 \mathrm{MPa}$ when reinforced with kaolin. The maximum stresses and fracture changed from 4.4 MPa to 5.6 $\mathrm{MPa}$ and from 3.5 MPa to 4.7 MPa respectively with the metakaolin-polymer composites. On the other hand, when the kaolin is used for reinforcement, the maximum stresses and fracture drops from 4.4 MPa to 3.3 $\mathrm{MPa}$ and from 3.5 $\mathrm{MPa}$ to $2.5 \mathrm{MPa}$ respectively. However, the tensile stress at break is the most important (56.3\%) with kaolin-polymer composites. This break is progressive in non-reinforced and reinforced with metakaolin plastic films, whereas the break is brutal in the case of kaolin-reinforced plastic film. This improvement in the mechanical properties is attributed to the dispersion state of metakaolin and more precisely to the interactions between the metakaolin particles and the polymer chains. These interactions reduce the mobility of the chains and thus improve the macroscopic stiffness of the composite [29] [30]. Some researchers have found similar values using sepiolite and montmorillonite as reinforcements. They observe an increase in Young's modulus and elongation at break [31]. But comparison is very difficult because starch mechanical properties strongly depend on the starch botanical source, the type and content of plasticizers as well as the storage relative humidity.

The behavior of the treated samples when heated was studied at different temperatures in a programmable oven (Figure 12). All plastic films remain 


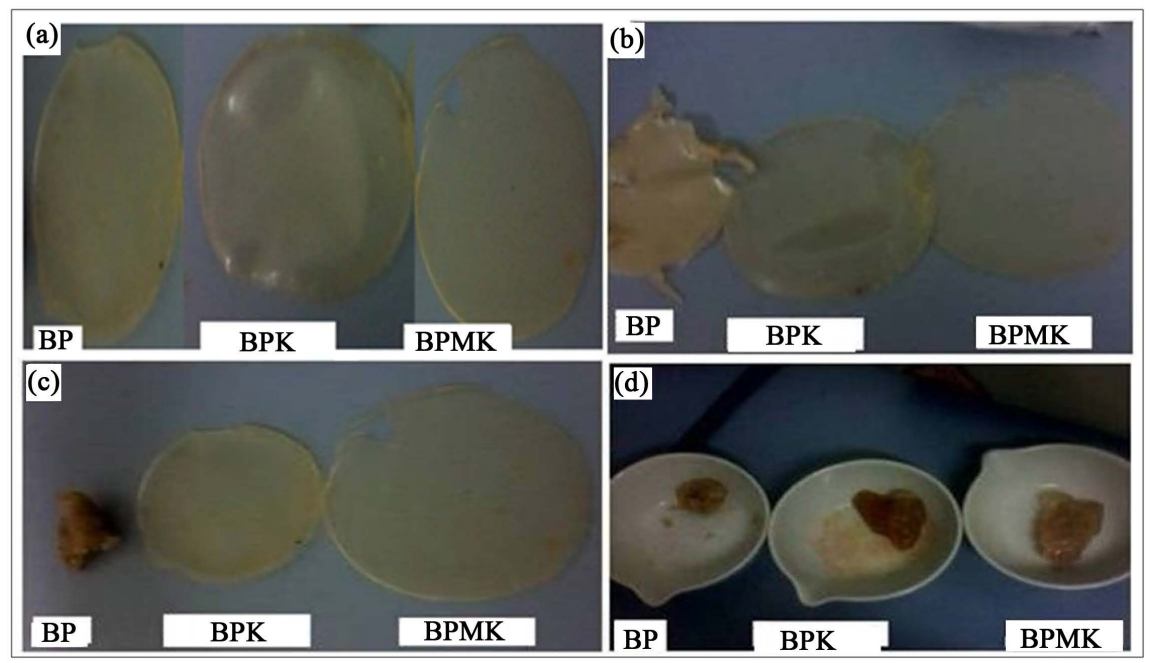

Figure 12. Thermal behavior at different temperatures of non-reinforced bioplastic, reinforced with kaolin and reinforced with metakaolin (a) $60^{\circ} \mathrm{C}$; (b) $90^{\circ} \mathrm{C}$; (c) $120^{\circ} \mathrm{C}$ and (d) $150^{\circ} \mathrm{C}$.

Table 2. Mechanical parameters in tensile testing of non-reinforced bioplastic, reinforced with kaolin and reinforced with metakaolin.

\begin{tabular}{cccc}
\hline Samples & BP & BPK & BPMK \\
\hline Maximum stress (MPa) & 4.4 & 3.3 & 5.6 \\
Breaking stress (MPa) & 3.5 & 2.5 & 4.7 \\
Breaking strain (\%) & 33.2 & 56.3 & 45.9 \\
Young's modulus (MPa) & $19 \pm 1$ & $7 \pm 1$ & $25 \pm 1$ \\
\hline
\end{tabular}

thermally stable up to $60^{\circ} \mathrm{C}$ and $90^{\circ} \mathrm{C}$, the non-reinforced plastic film is highly softened while the other two remain slightly affected by heat up to $120^{\circ} \mathrm{C}$. At $150^{\circ} \mathrm{C}$, all the plastic films are totally softened. The heat effect is later felt when the plastic films are reinforced with kaolin and metakaolin. This indicates that the mineral load acts as a thermal barrier [32].

\section{Conclusion}

The study of the improved starch-kaolinite plastic films revealed that the kaolinite does not interact with the polymer matrix resulting in poor structural and thermomechanical properties of the composite. This is attributed to the very cohesive nature of the layers of kaolinite and consequently a weaker dissolution of the element in the matrix. The Young's modulus decreased from $19 \mathrm{MPa}$ for the non-reinforced bioplastic to $7 \mathrm{MPa}$ for the bioplastic reinforced with kaolin. On the other hand, metakaolin, an amorphous material of disordered structure, is more favorable to surface dissolution and to a good dispersion of the layers in the matrix of the polymer. This contributes to strengthening the mechanical and thermal properties of plastic films based on metakaolin-reinforced cassava starch. The Young's modulus increases to $25 \mathrm{MPa}$ and the thermal resistance to 
above $120^{\circ} \mathrm{C}$ against $90^{\circ} \mathrm{C}$ for the non-reinforced bioplastic. Therefore, cassava starch reinforced with metakaolin, seems to be a very attractive alternative to replace plastics made from petroleum products. The applications envisaged for these new composite materials are the field of food packaging (disposable plates, plastic films, spoons ...) and they can also be used in 3D printers because of their interesting thermal properties.

\section{Acknowledgements}

The authors gratefully acknowledge the support of the European Ceramics Center (ECC) of Limoges (France).

\section{Declaration of Conflicting Interests}

The author(s) declared no potential conflicts of interest with respect to the research, authorship, and/or publication of this article.

\section{References}

[1] Plastics Europe, Plastics-The Facts (2015) An Analysis of European Latest Plastics Production, Demand and Waste Dataplastics. 1-30.

[2] Chen, B. and Evans, J.R.G. (2005) Thermoplastic Starch-Clay Nanocomposites and Their Characteristics. Carbohydrate Polymers, 61, 455-463. https://doi.org/10.1016/j.carbpol.2005.06.020

[3] Murray, H.H. (2000) Traditional and New Applications for Kaolin, Smectite and Palygorskite: A General Overview. Applied Clay Science, 17, 207-221. https://doi.org/10.1016/S0169-1317(00)00016-8

[4] Boudali, L.K., Ghorbel, A., Amri, H. and Figueras, F. (2001) Propriétés catalytiques de la montmorillonite intercalée au titane dans l'oxydation de l'alcool allylique (E)hex-2-én-1-ol. Comptes Rendus de P Académie des Sciences: Series IIC-Chemistry, 4, 67-72. https://doi.org/10.1016/S1387-1609(00)01211-1

[5] Mnasri, S., Besbes, N., Frini-Srasra, N. and Srasra, E. (2012) Étude de l'activité catalytique des argiles pontées aluminium, zirconium et cérium dans la synthèse du 2,2-diméthyl-1,3-dioxolane. Comptes Rendus Chimie, 15, 437-443. https://doi.org/10.1016/j.crci.2012.03.002

[6] Kouakou, L.P.M.S., Andji-Yapi, Y.J., Coulibaly-Kalpy, J. and Coulibaly, K.E. (2014) Argiles utilisées dans la curation de diverses affections en Côte d'Ivoire: Etude de l'effet antibactérien. Revue Ivoire Science et Technologie, 24, 84-92.

[7] Boffoué, M.O., Kouadio, K.C., Kouakou, C.H., Assandé, A.A., Dauscher, A., Lenoir, B. and Emeruwa, E. (2015) Influence de la teneur en ciment sur les propriétés thermomécaniques des blocs d'argile comprimée et stabilisée. Afrique Science, 11, 35-43.

[8] Konan, K.L., Sei, J., Soro, N.S., Oyetola, S., Gaillard, J.-M., Bonnet, J.-P. and Kra, G. (2006) Caractérisation de matériaux argileux du site d'Azaguié-Blida (Anyama, Côte d'Ivoire) et détermination des propriétés mécaniques de produits céramiques. Journal de la Société Ouest Africaine de Chimie, 21, 35-43.

[9] Murray, H.H. (1988) Kaolin Minerals: Their Genesis and Occurrences. In: S.W. Bailey, Ed., Hydrous Phyllosilicates, Mineralogical Society of America, 67-89.

[10] Mbey, J.A., Hoppe, S. and Thomas, F. (2012) Cassava-Starch Kaolinite Composite 
Film. Effect of Clay Content and Clay Modification on Film Properties. Carbohydrate Polymers, 88, 213-222. https://doi.org/10.1016/j.carbpol.2011.11.091

[11] Konan, K.L., Peyratout, C., Smith, A., Bonnet, J.-P., Rossignol, S. and Oyetola, S. (2012) Comparison of Surface Properties between Kaolin and Metakaolin in Concentrated Lime Solutions. Journal of Colloid and Interface Science, 339, 103-109. https://doi.org/10.1016/j.jcis.2009.07.019

[12] Soro, N.S. (2003) Influence des ions fer sur les transformations thermiques de la kaolinite. Thèse de doctorat, Université de Limoges, 48.

[13] Gardolinski, J.E., Carrera, L.C.M. and Wypych, F. (2000) Layered Polymer-Kaolinite Nanocomposites. Journal of Materials Science, 35, 3113-3119. https://doi.org/10.1023/A:1004820003253

[14] Zeppa, C., Gouanve, F. and Espuche, E. (2009) Effect of a Plasticizer on the Structure of Biodegradable Starch/Clay Nanocomposites: Thermal, Water-Sorption and Oxygen-Barrier Properties. Journal of Applied Polymer Science, 112, 2044-2056.

[15] Ma, X., Chang, P.R., Zheng, P., Yu, J. and Ma, X. (2010) Characterization of New Starches Separated from Several Traditional Chinese Medicines. Carbohydrate Polymers, 82, 148-152. https://doi.org/10.1016/j.carbpol.2010.04.057

[16] Mutungi, C., Onyango, C., Doert, T., Paasch, S., Thiele, S., Machill, S., Jaros, D. and Rohm, H. (2011) Long- and Short-Range Structural Changes of Recrystallised Cassava Starch Subjected to in Vitro Digestion. Food Hydrocolloids, 25, 477-485. https://doi.org/10.1016/j.foodhyd.2010.07.023

[17] Xie, Y., Chang, P.R., Wang, S., Yu, J. and Ma, X. (2011) Preparation and Properties of Halloysite Nanotubes/Plasticized Dioscorea opposita Thunb. Starch Composites. Carbohydrate Polymers, 83, 186-191. https://doi.org/10.1016/j.carbpol.2010.07.039

[18] Chen, Y., Cao, X., Chang, P.R. and Huneault, M.A. (2008) Comparative Study on the Films of Poly (vinyl alcohol)/Pea Starch Nanocrystals and Poly (Vinyl Alcohol)/Native Pea Starch. Carbohydrate Polymers, 73, 8-17. https://doi.org/10.1016/j.carbpol.2007.10.015

[19] Prabhu, D. and Rao, P. (2012) Coriandrum sativum L.-A Novel Green Inhibitor for the Corrosion of Aluminium in $\mathrm{HCl}$ Solution. Corrosion Science, 64, 253-262.

[20] Hamdy, A. and El-Gendy, N.S. (2013) Thermodynamic Adsorption and Electrochemical Studies for Corrosion Inhibition of Carbon Steel by Henna Extract in Acid Medium. Egyptian Journal of Petroleum, 22, 17-25. https://doi.org/10.1016/j.ejpe.2012.06.002

[21] Al-Amiery, A.A., Kadhum, A.A.H., Mohamad, A.B.S. and Junaedi, A. (2013) Novel Hydrazine Carbothioamide as a Potential Corrosion Inhibitor for Mild Steel in $\mathrm{HCl}$. Materials, 6, 1420-1431.

[22] Koffi, A.A., Muralidharam, S. and Trokourey, A. (2015) Mussaenda Erythrophylla Leaves as Effective Green Corrosion Inhibitor of Carbon Steel. Chemical Science Review Letters, 4, 1188-1198.

[23] Belibi, P.C. (2014) Elaboration et caractérisation des biofilms à base d'amidon de manioc renforcé par des charges minérales bi et tridimensionnelles. Thèse de doctorat, Université de Haute Alsace, Mulhouse.

[24] Ming, H. (2004) Modification of Kaolinite by Controlled Hydrothermal Deuteration-A DRIFT Spectroscopic Study. Clay Minerals, 39, 349-362.

[25] Madejová, J. (2003) FTIR Techniques in Clay Mineral Studies. Vibrational Spectroscopy, 31, 1-10. https://doi.org/10.1016/S0924-2031(02)00065-6

[26] Konan, K.L., Peyratout, C., Bonnet, J.-P., Smith, A., Jacquet, A., Magnoux, P. and Ayrault, P. (2007) Surface Properties of Kaolin and Illite Suspensions in Concen- 
trated Calcium Hydroxide Medium. Journal of Colloid and Interface Science, 307, 101-108. https://doi.org/10.1016/j.jcis.2006.10.085

[27] Lee, S., Kim, Y.J. and Moon, H.-S. (1999) Phase Transformation Sequence from Kaolinite to Mullite Investigated by an Energy-Filtering. Transmission Electron Microscope. Journal of the American Ceramic Society, 82, 2841-2848.

[28] Oudet, C. and Bunsell, A.R. (1987) Effects of Structure on the Tensile, Creep and Fatigue Properties of Polyester Fibres. Journal of Materials Science, 22, 4292-4298. https://doi.org/10.1007/BF01132020

[29] Kojima, Y., Usuki, A., Kawasumi, M., Okad, A.A., Fukushima, Y., Kurauchi, T. and Kamigaito, O. (1993) Mechanical Properties of Nylon 6-Clay Hybrid. Journal of Materials Research, 8, 1185-1189. https://doi.org/10.1557/JMR.1993.1185

[30] Chivrac, F., Gueguen, O., Pollet, E., Ahzi, S., Makradi, A. and Averous, L. (2008) Micromechanical Modeling and Characterization of the Effective Properties in Starch Based Nano-Biocomposites. Acta Biomaterialia, 4, 1707-1714. https://doi.org/10.1016/j.actbio.2008.05.002

[31] Chivrac, F.P., Schmutz, E. and Luc, M.A. (2010) Starch Nano-Biocomposites Based on Needle-Like Sepiolite Clays. Carbohydrate Polymers, 80, 145-153. https://doi.org/10.1016/j.carbpol.2009.11.004

[32] Averous, L. (2004) Biodegradable Multiphase Systems Based on Plasticized Starch. Journal of Macromolecular Science, C44, 231-274. 